Historic, Archive Document

Do not assume content reflects current scientific knowledge, policies, or practices. 



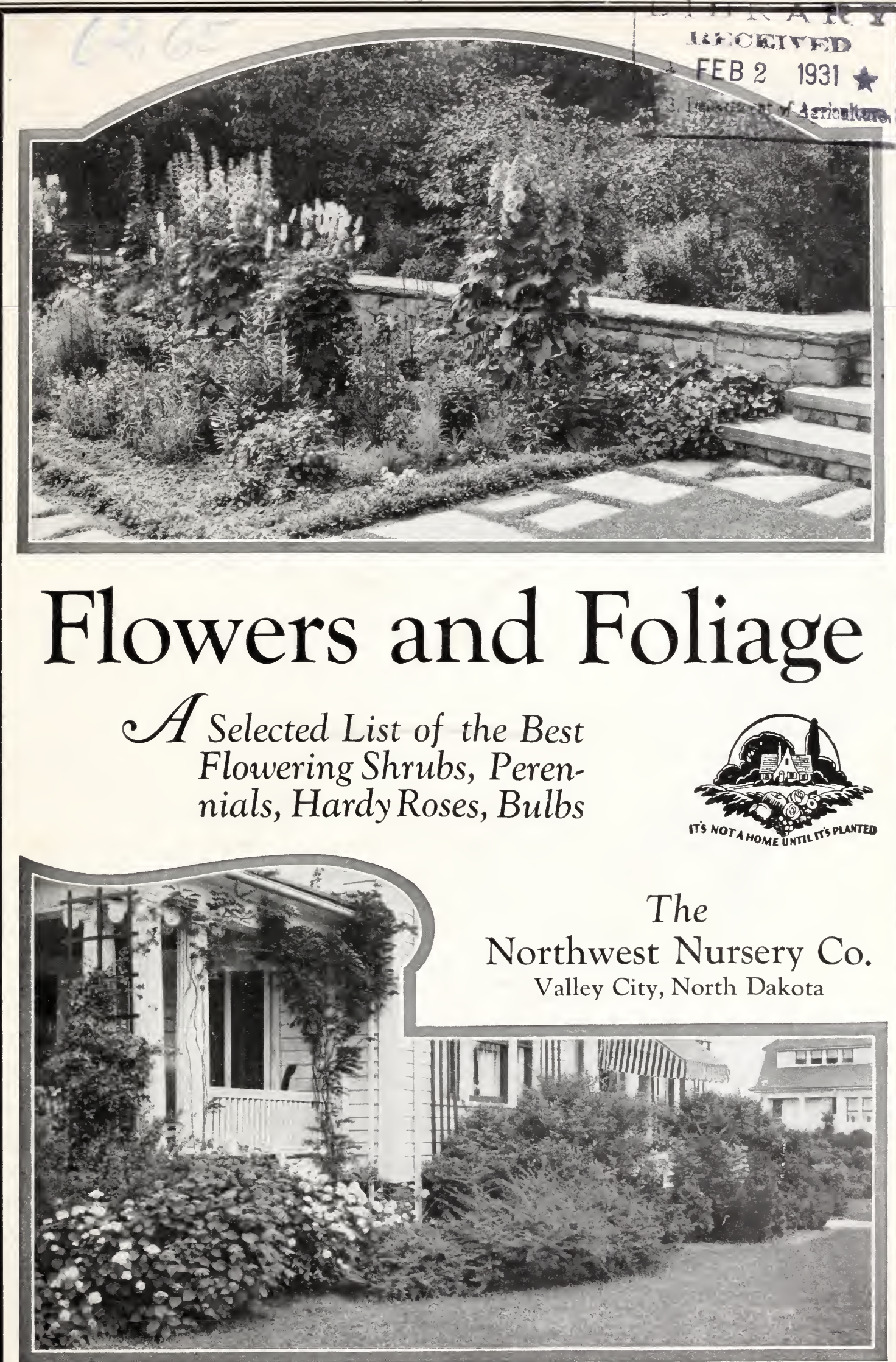




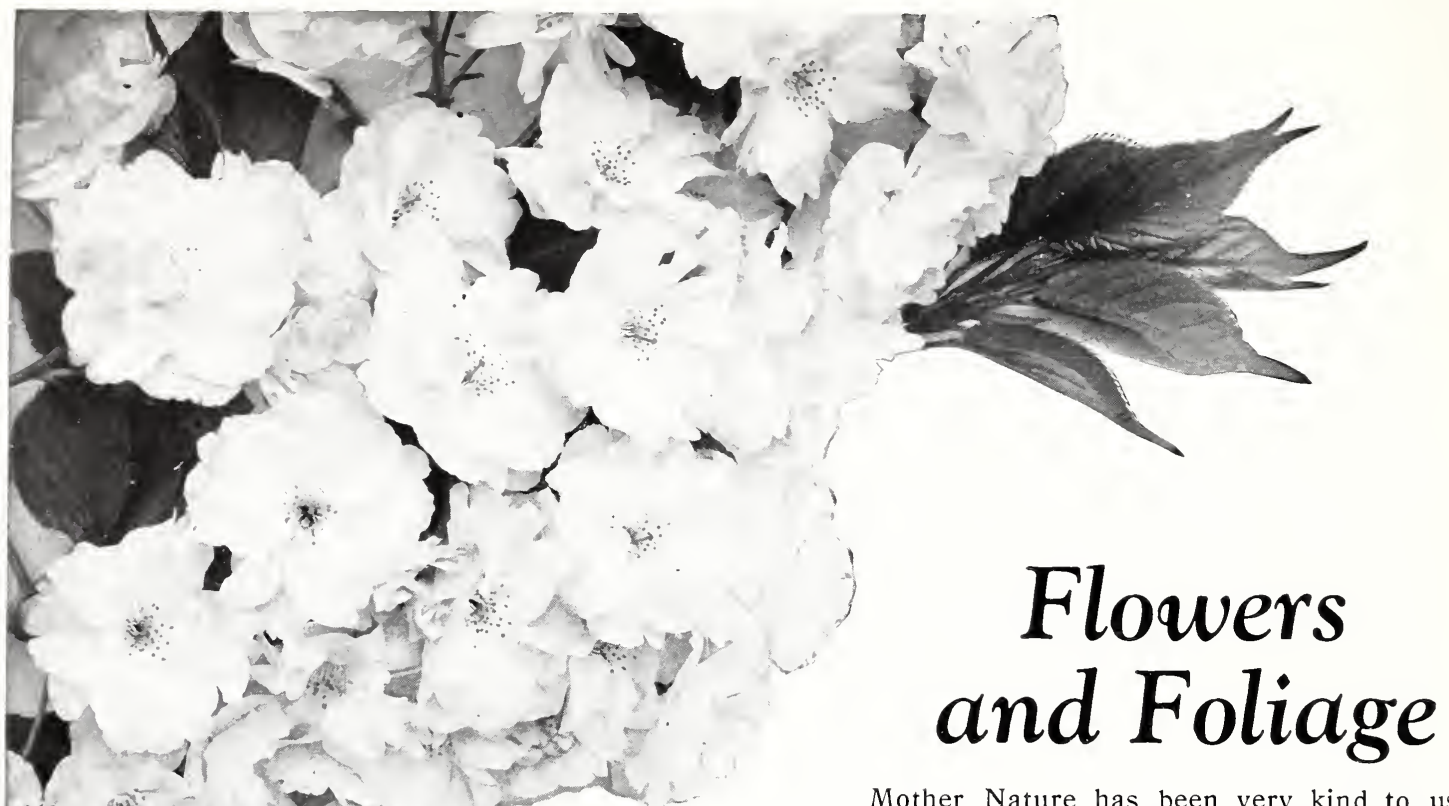

live in the given us a wealth of flowering shrubs that will benefit the homes in every part of this great region. But our expert gardeners and plant breeders have been able to cross most of these, and thus have produced varieties that far excel the plants we have found in our grandfathers' gardens. Just as livestock breeders have developed better prize animals that continue to break records, just so every season the plant specialists develop new varieties that surpass the old ones both in bloom and in foliage. For this reason certain varieties that were once favorites are discarded by prominent nurserymen and appear as bargains in many advertised lists.

It is the purpose of this nursery to keep up-to-date and grow for our patrons the newer and improved varieties. It costs no more to grow a better variety than an inferior one, but the satisfaction is much more real. In this catalog we offer our patrons a well chosen list that may be relied upon as "BEST OF THE WEST."

"Where shall I plant flowering shrubs?" Along the foundation of the house, in the corners of the walk, along the borders of the lot and at the back of the lawn. Plant these in groups so that they appear natural. Select your plants so that they will give a succes-

Prunus Triloba (Rose Tree of China). sion of bloom from early Spring until late Fall, so they will give you variety and form and color, and so they will provide Autumn coloring and late Fall berries.
These problems are all made clear in our little booklet entitled the "Amateur's Guide to Landscape Gardening" which may be had for the asking. This nursery provides a landscape department to assist its patrons. Feel free to ask for help. Remember our aim - to furnish the home owners of this great Northwest region with a better list of plants, to supply them with well grown, well developed plants of strong grades that are safely handled and packed so they will grow, and to give to these home owners a sensible service at a popular price. Read the following pages and proceed to add beauty and value to your home grounds.

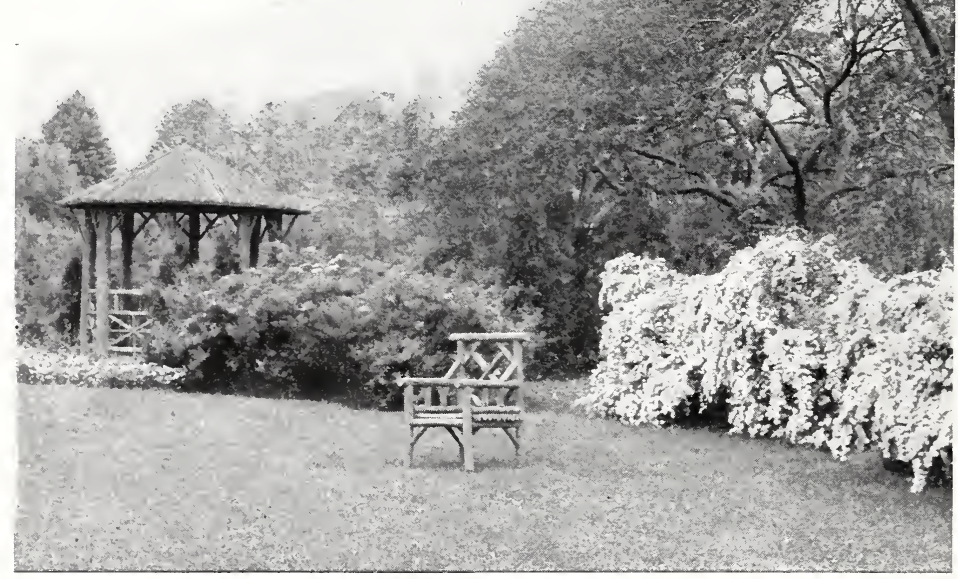

In Outdoor Living Room. 


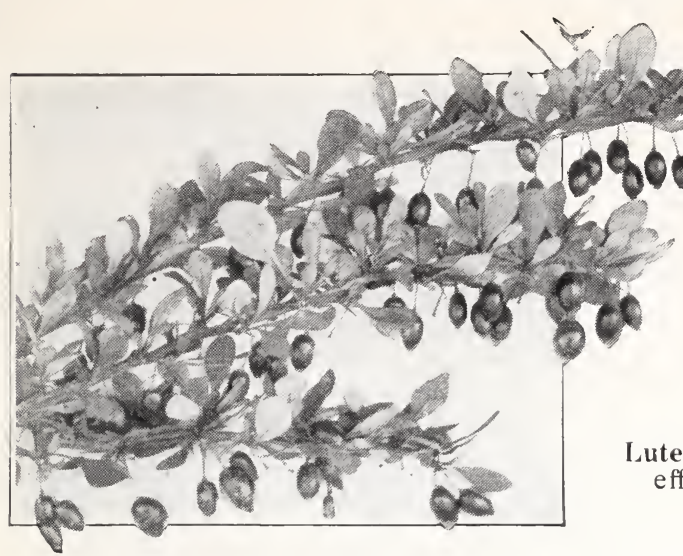

\section{Japanese Barberry}

This Barberry does not spread rust. One of the best all around shrubs for the Northwest, thriving under all conditions. Slender, graceful branches with fine, bright green foliage, turning to brilliant crimson and orange in the Fall. Branches are covered with small, yellow flowers in June, followed by scarlet berries that stay on the bushes almost all Winter. One of the best for shrubbery borders and low hedges. 2 to 3 feet.

\section{Caragana}

Arborescens. One of our hardiest desirable shrubs. During early May the bush is covered with bright yellow, pea-shaped flowers, followed by long, slender pods. Pretty as a lawn shrub or for hedges. Especially valuable in dry locations and where soil conditions are not the most favorable. 6 to 12 feet.

Pygmaea. A dwarf, low-growing, dense Caragana with fine limbs and texture. Very valuable for dwarf hedges and borders.

\section{Coralberry}

\section{(Symphoricarpos vulgaris)}

July. Resembles S. racemosus in growth but is a little more compact. The flowers are borne in dense terminal spikes. They are followed in late Summer by dark purplish red berries, hanging in clusters. Well adapted for shady places. 3 to

\section{Cornus}

Sibirica (Red Twigged Cornus). A tall, spreading shrub, which is extremely hardy, and splendid for hedges or groups of shrubbery. Panicles of white flowers in June are followed by clusters of berries. Its chief beauty, however, is in its bark, which turns bright crimson as Autumn approaches. Planted extensively for Winter effect. Will thrive in shady locations. 6 to 10 feet.

A yellow branched form of the Siberian, used very ffectively for contrast. 6 to 10 feet. June.

Elegantissima. One of the choicest variegatedleaved shrubs with purplish red branches and leaves beautifully variegated with silver. 4 to 6 feet.

\section{Cotoneaster}

Acutifolia. An attractive, beautifully formed shrub with thick, glossy leaves turning red in the Fall, giving it the most attractive appearance. The flowers, which appear during the early Summer, are followed by large, black berries, which remain on the bush nearly all Winter. Absolutely hardy and stands partial shade. Splendid in shrub plantings and unexcelled for hedges. 5 to 6 feet.

CRANBERRY. (See Viburnum).

\section{Currant}

Alpine (Ribes alpinum). A most desirable lowgrowing shrub. On account of retaining its foliage close to the ground it makes a desirable plant for shrubbery borders. One of the best shrubs for shady places; excellent for hedges. 4 feet.

Yellow Flowering (Ribes aureum). Large, yellow, showy flowers are produced in clusters early in the Spring. Later the bush is covered with a crop of dark brown or black berries which may be eaten. 5 to 8 feet.

4 feet.

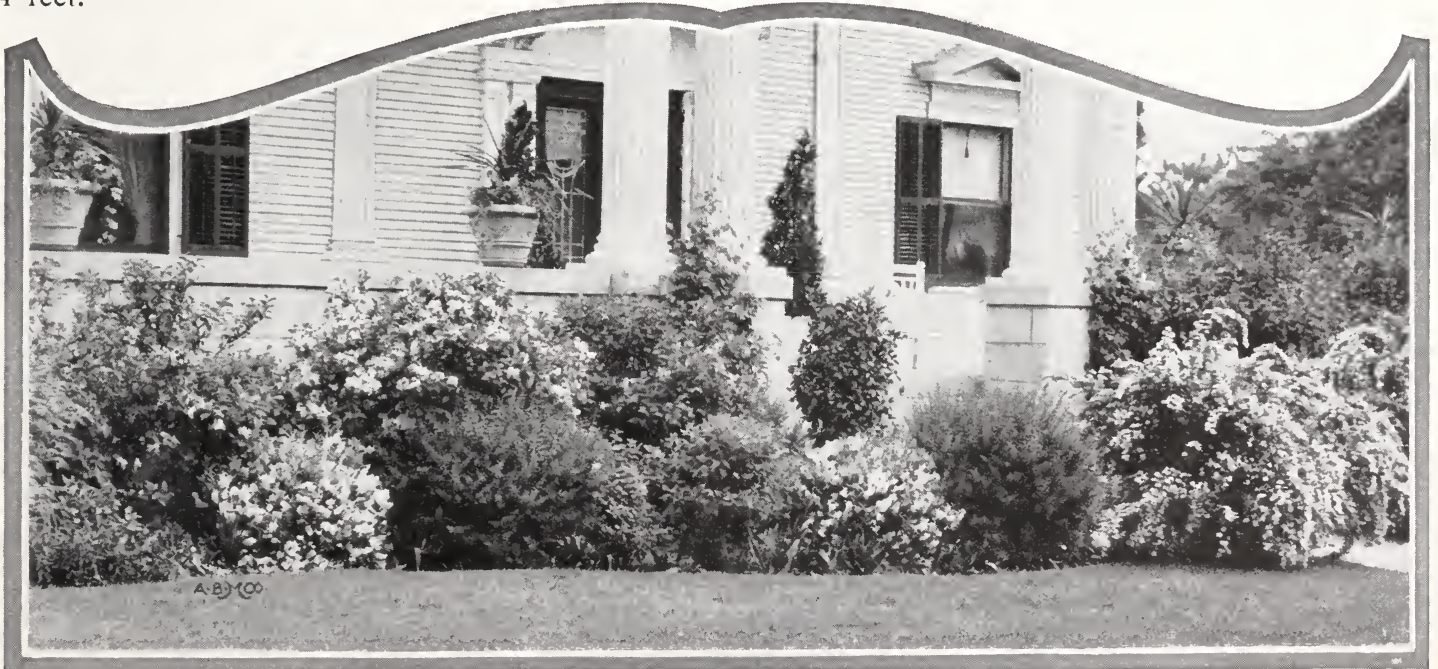




\section{Elder}

Fern Leaf (Sambucus canadensis laciniata). This is one of our finest shrubs. A large busin, covered with clusters of large, flat flowers, giving en masse somewhat the effect of the hydrangea. The foliage is lacelike, with a cut fern appearance. Will thrive in shady location. 5 to 6 feet.

Red-Berried (Sambucus racemosa). Flowers yellowish white, bush covered with scarlet fruit in late Summer. Grows to 8 feet.

Golden (Sambucus aurea). Contrasted with other shrubs, the golden leaves of this Elder give heightened effects in tone and color. The leaves are a beautiful bright gold from first appearance in the Spring until they drop in the Fall. The best of our golden-leaved shrubs. 5 to 7 feet.

\section{Honeysuckle}

Morrowi (Lonicera Morrowi). This is one of the best quick growing, compact, "filler" shrubs we have. The foliage is bright green, the blossoms cream colored, appearing in April. The red and coral fruits follow from June to August. In dry or moist soil, shade or sun, city or country, this variety will thrive. 6 feet.

Tartarian (Lonicera tatarica). Pink. April. This is very attractive in blossom, being one of the few early pink-flowering shrubs. Has bright red berries that stay on all Summer. 7 to 9 feet.

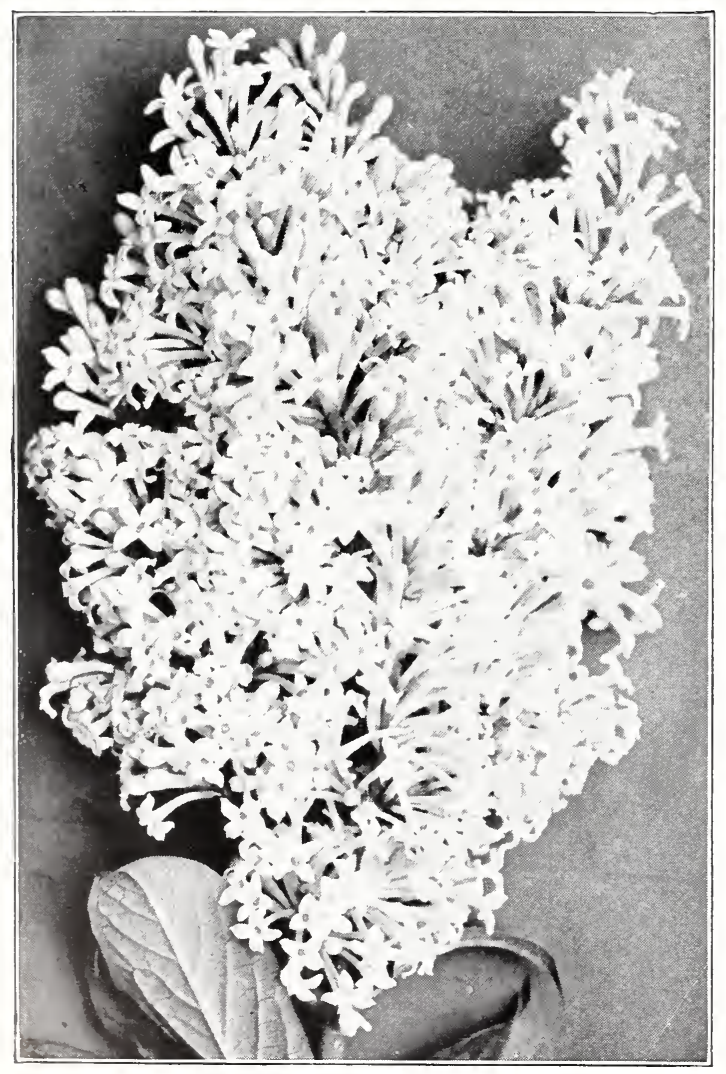

Villosa-Japan Lilac.

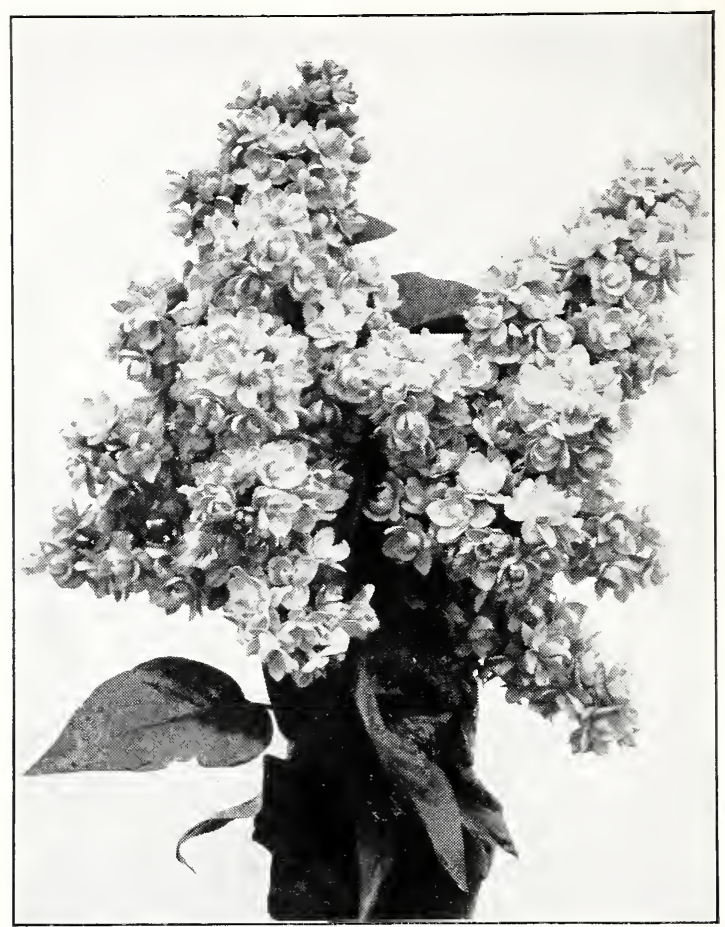

Lilac, President Grevy.

\section{Hydrangea}

Paniculata (var. grandiflora). August and September. The showiest of all Autumn-flowering shrubs, bearing immense heads of creamy white flowers which, with the approach of cold weather, turn to rich shades of pink and coppery red. Taken into the house before frost, they hold their form and color and make attractive decorations throughout the Winter. 4 feet.

Hills of Snow or Snowball Hydrangea (Hydrangea arborescens grandiflora). A new valuable shrub with large, snow-white blossoms of immense size. The habit of the plant is excellent, the foliage finely finished. Commences to bloom in June and continues until early Fall. Coming into bloom at a season when most shrubs are through flowering, makes it a valuable acquisition in any garden. Recommended as one of our best shrubs. 3 to 4 feet.

\section{Lilacs}

No group of flowers have gained in popularity so rapidly as the Lilac. Throughout the land a new interest in Lilacs has arisen due largely to the many beautiful new hybrids which have been developed. We can now offer Lilacs in a wide range of colors through white, pink, lavender, red, blue and dark purples. Both in single and double flowers. Lilacs produce an abundance of flowers in Spring and early Summer, filling the air with their delicate fragrance. Lilacs have no diseases nor pests. They are easy to grow. Some varieties bloom early, others late, which offers a wide range in season as well is in color. The list offered below is the very choicest list of the best varieties. The new hybrid Lilacs do not produce suckers.

Common Purple. This is the old-fashioned flower so familiar in our grandmothers' gardens. Some of these ought to be in every collection. 9 to 12 feet. 


\section{LII.ACS-Continued.}

Common White. Similar to the above, with pure white flowers. 9 to 12 feet.

Japan Tree Lilac (S. japonica). Late June. A distinct variety forming a pyramidal and upright shrub or small tree. It has broad, handsome, dark green foliage and bears large heads of creamy white flowers very late in the season, a month after the common Lilacs. 10 to 15 feet.

Persian (S. persica). May and June. A distinct species of rather smaller growth than S. vulgaris. The branches are slender and straight with smaller and narrower leaves. The bright purple flowers are borne in loose panicles. A very graceful form. 5 to 6 feet.

Villosa. Flowers light purple in bud and nearly white when open. Fragrant; late bloomer. 8 to 10 feet.

\section{"NEW HYBRID LILACS"}

We recommend the following as being the best.

$$
\text { S-Single D-Double }
$$

Alphonse Lavallee. D. Blue shading to violet; very large.

Belle de Nancy. D. Double flowers in great panicles; satiny rose.

Chas. X. S. One of the best known and most popular of the hybrid improved Lilacs; thrifty, strong grower. Large trusses of reddish purple.

Congo. S. Flowers dark wine-red; large and showy.

Ludwig Spaeth. S. Deep purplish red in large, long, dense panicles.

Marie Legraye. S. Large panicles of white bloom borne in great profusion.

Mme. Casimir Perier. D. Creamy white; superb.

President Grevy. D. A beautiful blue; individual flowers very large and double.

Rothomagensis. S. A hybrid of the Persian Lilac which grows with the same general form and thrifty habit as the Persian. Bears a great profusion of reddish purple flowers in heavy trusses. Very fine and satisfactory.

Wm. Robinson. S. Nearly red; long spikes; handsome.

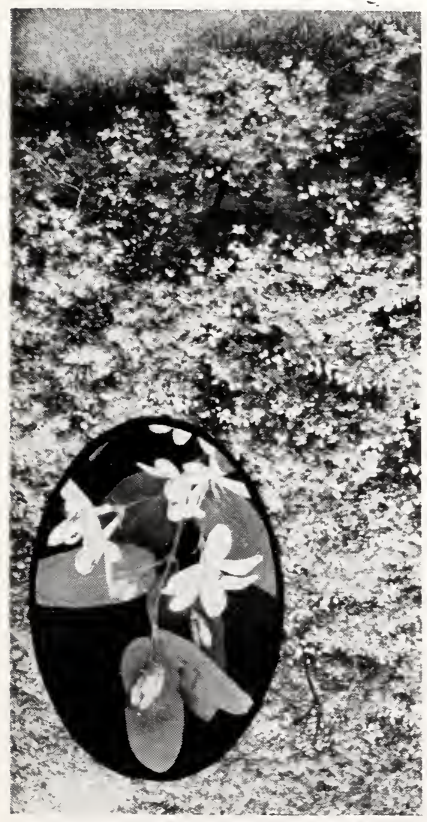

Honeysuckle Morrowi.

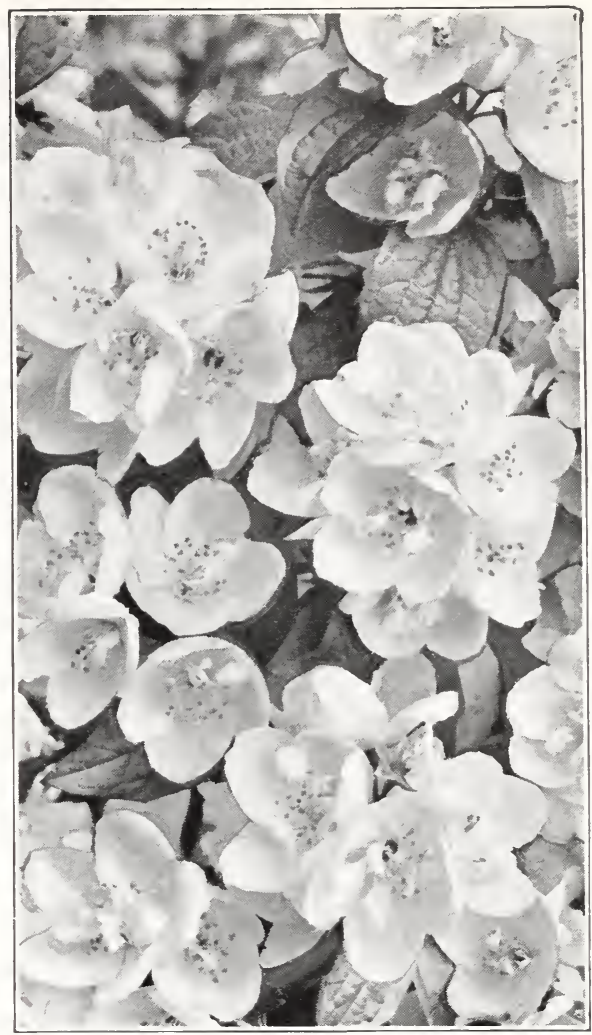

New Hybrid Philadelphus Virginal.

\section{Maple}

Ginnala. A shrubby dwarf tree of true maple foliage, finely cut leaves. Brilliant red foliage in Autumn, hardy and easily transplanted, worthy of a place in every garden or park.

\section{Philadelphus}

Coronarius (Mock Orange: Syringa). White. June. The old-fashioned Mock Orange, well known to everyone because of its waxy white, fragrant flowers. It proves a specially good plant for every use, the foliage being large, oval in shape and deep green. Very valuable for background, screen or grouping. 7 to 8 feet.

Lemoine (Lemoine Syringa). The blooms of this variety, and of the other sorts originated by Lemoine, are considerably larger than those of the common Mock Orange, although the growth is not so tall. In June the shrub is covered with fragrant, semi-double blooms. 4 to 5 feet.

Virginal. A magnificent new variety. Moderately tall, with good foliage and compact habit. The flowers (fully double, semi-double and single), are the largest, handsomest, and most sweetly fragrant of any known variety.

PLUM, FLOWERING. (See Flowering Cherries and Crabs).

\section{Russian Olive}

A showy shrub or small growing tree. It has peculiar silvery, olivelike leaves, light green above and silvery white beneath. Used in landscape work for marked foliage contrast effects. 10 to 15 feet.

SNOWBALL. (See Viburnum).

\section{Snowberry}

(Symphoricarpos racemosus).

Usually 3 to 5 feet tall, with numerous spreading branches. The flowers are followed by white berries which remain on the bush until Winter. Excellent for grouping or massing. They will grow under trees in dense shade and succeed in poor soil where practically nothing else would grow. 


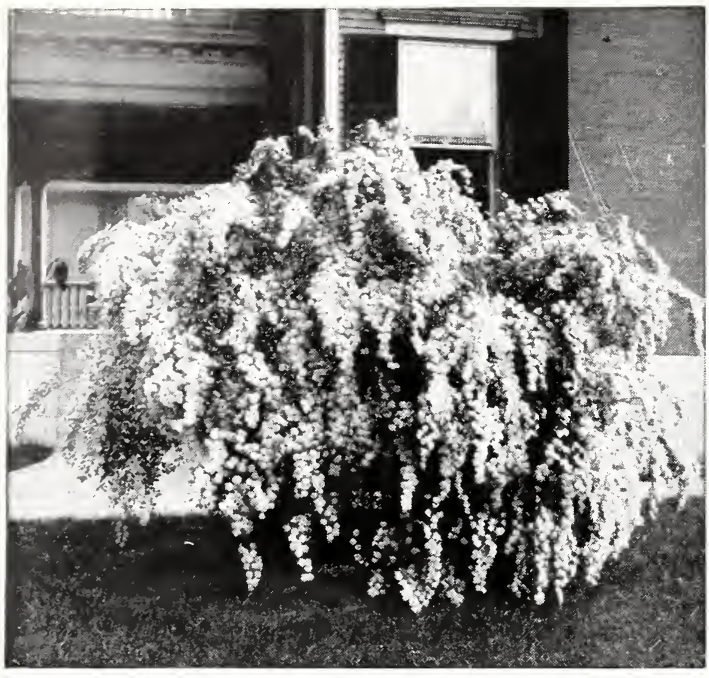

Spiraea Van Houttei.

\section{Spiraea}

In the Spiraea family are found quite a number of varieties, some of which differ so widely that a person unacquainted with them would never realize that they had any points in common. Practically all of them bloom profusely, and if a good selection of varieties is made, some of them will be in bloom at all times during the Summer season. All of them are extremely hardy and quite easy to grow. There is almost no place about the grounds for which some Spiraea will not be suitable.

The following are the best of the Spiraea family:

Billardi. Grows 4 to 5 feet high. Bright pink flowers are borne on spikes. Blooms in July and August. Extremely hardy.

Callosa alba. Dwarf white Spiraea of bushy, symmetrical form. Keeps in flower nearly all Summer. A valuable small shrub. 2 feet.

Froebeli. Flowers bright rosy red in flat clusters, produced during July and August. This is one of our finest Spiraeas, excellent as a border shrub. Foliage turns purple in the Fall. Branches willowy. Should be in every garden. 3 feet.

Margarita. A handsome free-flowering type, medium high with large, bright pink flowers in broad corymbs.

Opulifolia aurea. Growth upright, attaining a height of 8 to 10 feet. The heavy white flowers in June cause the branches to droop. The young foliage of bright yellow changes to golden bronze in the Fall.

Sorbifolia. A splendid Spiraea, covered with large, clean, bright green leaves that resemble the leaves of the Mountain Ash. Produces a world of great white feathery blooms about six inches long by four inches in diameter. 3 to 4 feet.

Snow Garland. Semi-dwarf. The Snow Garland is one of the newer varieties that has been developed from a cross between the well known Bridal Wreath and Thunberg's Spiraea. The Snow Garland is the first of the Spiraea family to bloom. In early Spring, while tulips are still in flower and before the leaves are out, it bursts into full bloom with a profusion of white flowers that cover its graceful branches like a bank of snow. It is ideal to plant in front of Spiraea Van Houttei. As its flowers begin to fade it seems to pass to the unfolding Bridal Wreath,

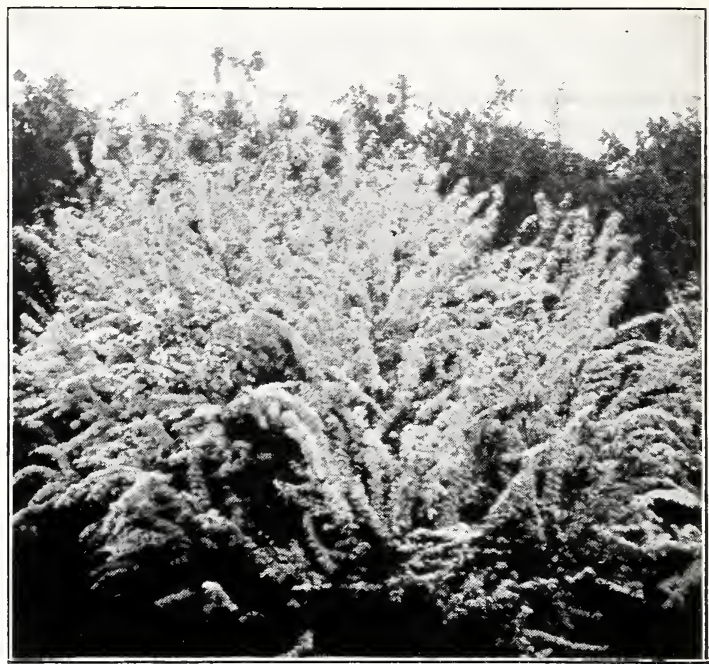

Snow Garland Spiraea.

thus giving six weeks of the much desired Spiraea bloom. The foliage of this plant is very attractive, producing pleasing Autumn colors and much of the foliage is retained throughout the Winter. Perfectly hardy. 3 to 4 feet.

Van Houttei. Often called Bridal Wreath. If there is one shrub that stands pre-eminently above all other ornamental plants, it is undoubtedly the Spiraea Van Houttei. The long branches, curving and reaching to the ground, are covered the entire length with lovely white blossoms, like a great fountain of snow. It begins to blossom about the time the Spiraea Arguta is through, thus giving a succession of similar bloom lasting for four weeks or more. Extremely hardy; will thrive anywhere. This variety can be used in any location for hedging, grouping or for mass effect. 5 to 6 feet.

\section{Sumac}

Cut-Leaved Staghorn (Rhus typhina laciniata). A new shrub and one of the most beautiful plants in nature. It is of spreading habit, with large, long, finely cut, lacelike, wonderfully graceful leaves. The foliage is a pleasing green, always healthy and clean, and turns in Autumn to varied hues of pink, crimson and gold. 6 to 10 feet.

\section{Viburnum}

Viburnum lantana (Wayfaring Tree). Wonderfully attractive shrub with wrinkled whitish leaves white flowers in May and June. Berries colored unequally from crimson to black, causing a most charming array of color throughout the Summer.

V. opulus sterile (Snowball). That good old bush that hardly seems to need description so well known it is. A tall growing, absolutely hardy shrub covered in late May and early June with great masses of snowball-like blooms. Requires plenty of moisture.

V. opulus (High Bush Cranberry). Handsome, native shrub. Flowers white in flat clusters. Very decorative in fruit which begins to color by the end of July, remaining on the branches and keeping its bright scarlet color until the following Spring. Ornamental as well as useful. A large growing shrub closely allied to the Snowball. 8 feet. 


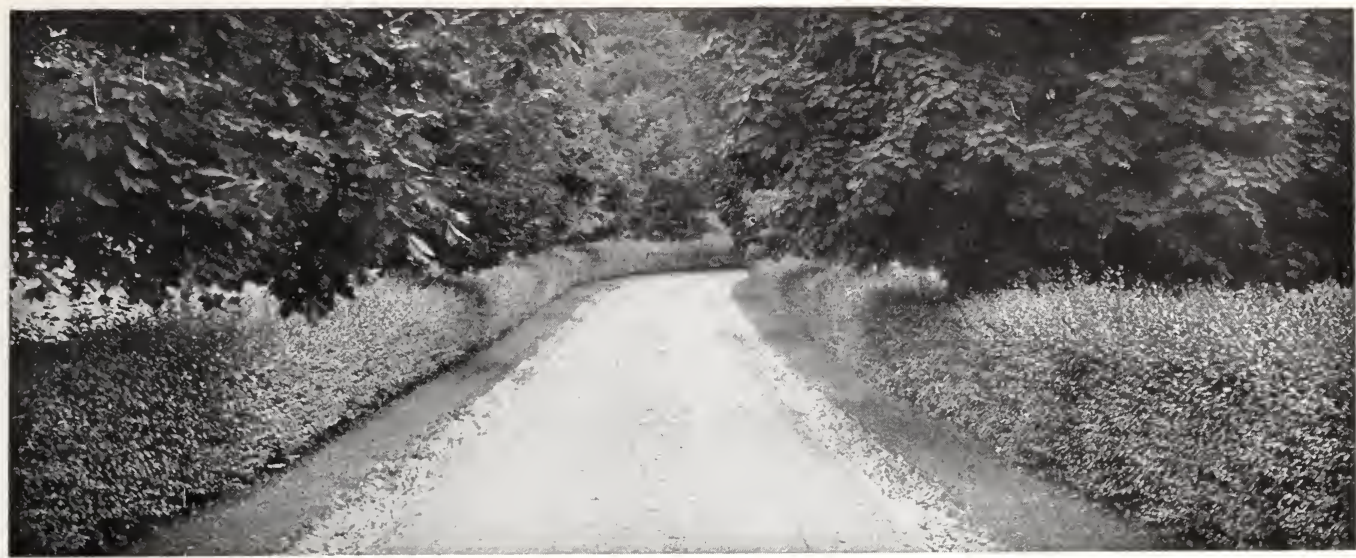

Cotoneaster IIakes a Beautiful Hedge.

\section{Flowering Cherries and Crabs}

CISTENA. Purple Leaf Sand Cherry Hybrid produced by Prof. Hansen. Cross between Purple Leaf Sand Cherry and Purple Plum. We consider this the finest of all the purple-leaf shrubs. Very striking.

CRATAEGUS (Hawthorn). Hawthorn is gaining rapidly in popularity. This variety was found growing in the Minnesota woods. Very striking. Branches in flat layers, masses of white bloom in Spring followed by brilliant red thorn apples.

DOLGO (Flowering Crab). Beautiful ornamental, thrifty, upright growing tree, heavy dark foliage; fruit is borne in clusters of rich red-red all over. Very striking. We believe this to be the most beautiful fruit tree in existence. Fruit excellent for cooking.

HOPA (Red Flowering Crab). This beautiful flowering Crab was produced by Prof. Hansen. Thrifty tree covered in Spring with masses of double red flowers. Perfectly hardy anywhere in the United States. Fruits purple.

PRUNUS TRILOBA (Rose Tree of China). An interesting shrub of medium height, bearing early in May, a profusion of delicate pink, roselike blossoms appearing just before the leaves unfold. Without doubt one of the prettiest shrubs we have. (See cut on page 2). 5 feet.

\section{Hedges-Beautify as Well as Serve}

Within the past few years hedges have come to be very popular. They give privacy and protection; at the same time add greatly to the beauty of each individual place. Home grounds that are not finished off with a hedge present the appearance of a picture without a frame. From the list below you can select a suitable hedge for any place.

\section{Barberry, Japanese}

Does not spread Rust. For a low-growing, informal hedge nothing is lovelier than the Japan Barberry (Berberis Thunbergi). It is absolutely hardy, thorny enough to make an effective hedge against small animals, and requires no pruning, as it does not grow tall. The small, light green leaves are beautiful all Summer, and in the Fall turn a brilliant scarlet; and stay on until quite late. Even after the leaves are gone, the scarlet berries give a striking touch of color through the Winter months. $21 / 2$ feet.

\section{Buckthorn}

A well known ornamental hedge plant that stands close pruning without injury. Where trimmed the leaves soon cover the cut, making the hedge appear like a smooth and glossy wall of living green. The leaves are of a rich, healthy green color, remaining in perfect condition throughout the Summer. In order to get a pretty hedge the plants must be trimmed severely the first few years so as to get numerous strong branches near the ground. Some hedge plants are very particular as to the time for trimming, but not so with the Buckthorn. It will stand trimming at any time.

\section{Caragana}

(Siberian Pea Tree).

For a low hedge, plant a foot apart. For a screen, plant five feet apart. Delicate foliage, similar to that of the locust, with bright yellow flowers in May.

\section{Cotoneaster}

This makes a most attractive, dense, lustrous, dark green hedge. The thick glossy leaves turn to brilliant Autumn colors in the Fall and stand partial shade, resist drought, is absolutely hardy and responds well to trimming. Fast becoming a popular hedge in the Northwest.

\section{Currant, Alpine}

We believe that of all the hedges for the Northwest, the Alpine Currant is by far the aristocrat of them all. Its fine cut foliage, natural tendency to grow dense, its dwarf growth and hardiness combined, make it one of the most desirable hedges available.

\section{Spiraea Van Houttei}

Another most pleasing hedge plant is Spiraea Van Houttei. The long, graceful, drooping sprays are attractive even after the flowers are gone, and grows just about the right height to give privacy without "shutting in" the place; it is especially" good for the back or side lines of the place, under most conditions, although a little too tall for the front. 


\section{Hardy Roses}

Everybody loves Roses. For years people have tried to raise them here in the North, but with indifferent results. This was due to the fact that most of the older varieties needed protection in the Winter and spraying in the Summer, and this care was seldom given. However, an entirely new strain of Roses has been developed which are hardy enough to stand the Winters without covering and whose foliage is healthy and vigorous and is seldom attacked by insects or diseases. This new type of Rose, the HYBRID RUGOSA, makes it possible for everyone to enjoy in their own yard the queen of all flowers.

We strongly advise our patrons to secure not only one, but the complete collection, as each has peculiar merits which will delight all lovers of the Rose, and which we of the North are privileged to enjoy to the full. Will make a valuable hedge.

\section{Hybrid Rugosa}

Agnes. Beautiful new Hybrid Rugosa; pure yellow. Developed by the Government Station at Ottawa, Kansas. Parentage double Rugosa and Persian Yellow. Fine double; wonderful foliage; perfectly hardy. The only known pure yellow Rugosa.

Amelie Gravereaux. The newest and choicest of Rugosa Hybrids. The flowers are a rich red American Beauty color, large, single stem blossoms, of rich fragrance. It is a liberal bloomer-often carrying a dozen blooms within eight weeks after planting. A hardy and thrifty bush of beautiful foliage-a real attraction as a shrub. We consider this new creation the "Rose Par Excellence" for the Northwest.

Belle Poitevine. Double pink Hybrid Rugosa. Foliage heavy, very hardy. One of the most prolific and satisfactory Hybrid Rugosas. Blooms heavily the first season and throughout the Summer.

Blanc de Coubert. One of the finest Rugosas. Semi-double, ivory-white bloom, exceedingly hardy, lustrous foliage. Excellent for specimens or hedges.

Dr. E. M. Mills. Seedling of Hugonis. The same acacia-like type of foliage, but grows lower, more compact, with long, arching branches. Covered in Spring with a wreath of blush pink Roses. Very valuable in foundation or borders.

Grootendorst. Clear bright red. This novelty is a most valuable acquisition, having the clean, leathery foliage of the Rugosa Roses and the low-growing habit and continuous blooming of the Baby Rambler. The flowers are borne in clusters. They are of good size for this class of Rose, are nearly double and the edges of the flowers are beautifully fringed. The color is a fine clear red and holds exceptionally well. The bloom is produced continuously from early Summer until cut off by cold weather in the Fall. The foliage is of the true Rugosa type and is always healthy, attractive and free from mildew.

It is very effective, not only for planting singly as specimens, but is especially valuable for landscape work in low massing.

Grootendorst, Pink. This popular new Rose developed from a pink sport bud of the red Grootendorst. Otherwise the same.

Hansa. Deep violet-red. Very large, perfectly double, fragrant. In this fine variety, unlike most of its class, the buds of each cluster open at about the same time, giving the effect at a distance of a single Rose of immense size. The foliage is particularly dark, rich green and the bush absolutely hardy.

Sir Thomas Lipton. Pure white. Fragrant, perfectly double. The type of bush is similar to the Amelie Gravereaux and makes an excellent white to plant with that beautiful red.

\section{Other Hardy Roses}

Harrison's Yellow. A perfectly hardy rose, strong growing bush covered in early June with a mass of small semi-double golden yellow flowers, very fragrant. Thrives in any soil and will stand rather dry conditions. Very dependable.

Hugonis. The Golden Rose of China, a striking attractive rose shrub; hardy, thrives best in sunny and dry locations. Long wreaths of beautiful golden single roses are borne on last year's canes. The foliage of acacia-like leaves is very striking.

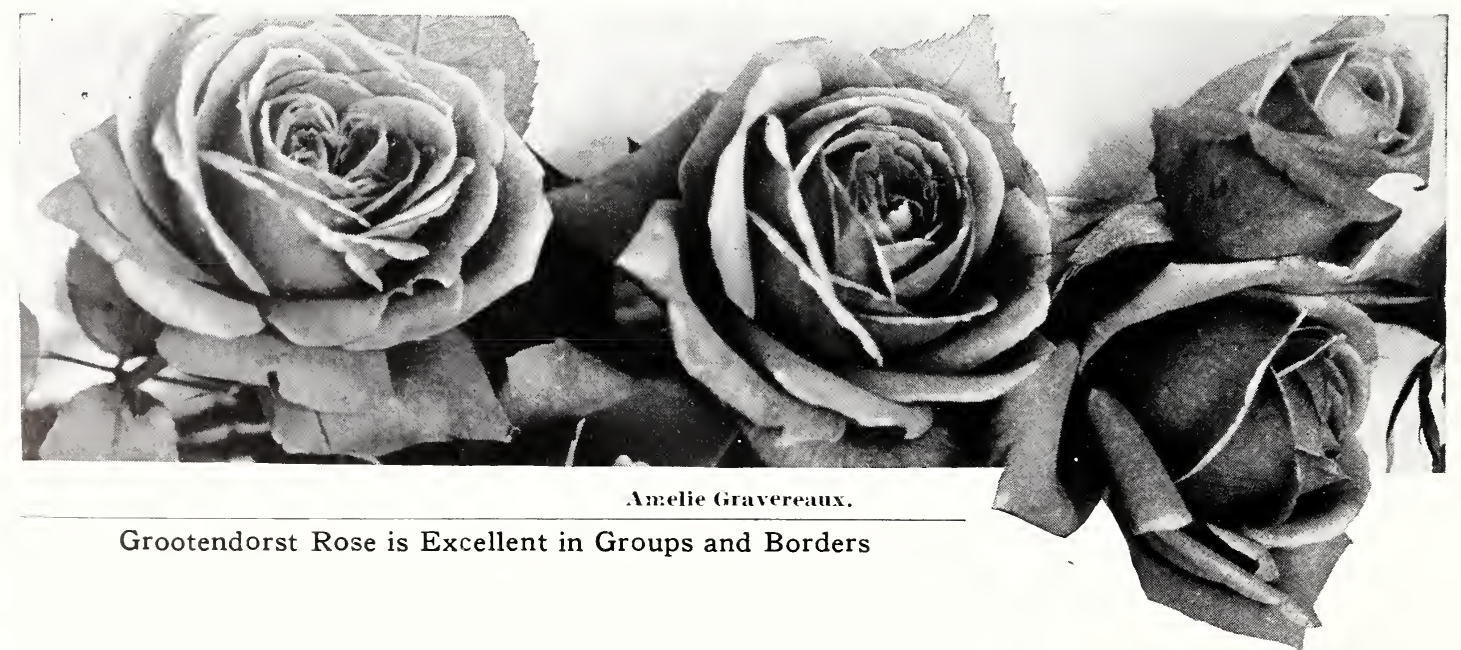




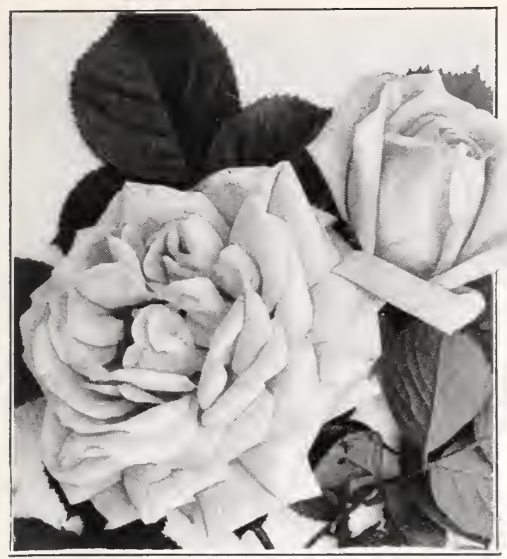

Hansa.

\section{Standard Roses}

Requiring Winter Protection.

Frau Karl Druschki. White.

Gruss an Teplitz. Also called Prairie King.

Paul Neyron. Pink.

Red Radiance. Vigorous, upright, bushy plants, bearing a continuous supply of very large, beautiful, deep red flowers.

\section{Climbing Roses}

Dorothy Perkins. Clear cherry-pink. Slightly fragrant flowers borne in great profusion, and lasting for a long time. They are double and the petals crinkled, which gives them a delightful fluffy appearance. Foliage is glossy bright green, and persists until cold weather.

Excelsa. "A Red Dorothy Perkins." An intense crimson, with the edges of the petals a little lighter, produced in immense clusters. Very similar to Crimson Rambler, but much superior to it in color of flower, and in the glossy, diseaseresistant foliage.

\section{Hardy Climbing Vines}

Aristolochia, Sipho (Dutchman's Pipe Vine). A vigorous and rapid growing climber, bearing singular brownish colored flowers, resembling in shape a pipe. Its flowers, however, are of little value compared to its light green leaves, which are of very large size, and retain their color from early Spring to late Fall; perfectly hardy.

Clematis, Andre. Flowers large, of a beautiful, bright velvety red; very free-flowering and continuous bloomer.

Clematis, Jackmani. Very profuse blooming with flowers from four to six inches in diameter, of an intense violet-purple; borne in continuous masses on the Summer shoots. Best sort for general planting.

Clematis, Henryi. Fine bloomer, flowers large, of a beautiful creamy white, generally of from six to eight petals. June to October.

Clematis, Paniculata. Of rapid growth, quickly covering trellises and arbors with handsome, clean. glossy foliage. Flowers are of medium size, fragrant, pure white borne in immense sheets in September, when few other vines are in bloom; hardy.

Chinese Wisteria. One of the most rapid growing of all the climbing vines. It grows from 15 to 20 feet in a season. Has long, pendulous clusters of pale blue flowers in May or June.

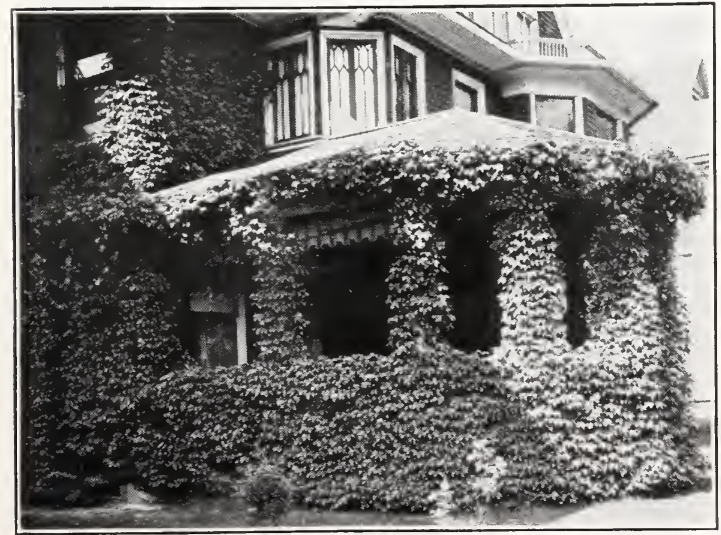

Engelmann's Iry.
Honeysuckle, Scarlet Trumpet (Lonicera). The old garden favorite, blooms all Summer, producing the most brilliant orange-scarlet flowers. Foliage rich, glossy green.

Honeysuckle, American (Sometimes called Woodbine and Virginia Creeper). A native of the Dakotas. Absolutely hardy and vigorous. A more rapid grower than Engelmann's Ivy but it requires a trellis upon which to climb.

Honeysuckle, Engelmann's (Ampelopsis Engelmanni). The best climbing vine for this climate, to cover brick or stone walls or any rough surface, as it clings without a trellis. It is a very rapid grower, often growing 15 to 20 feet in a single season. In appearance it resembles the Common Virginia Creeper, but the leaves are smaller and the whole vine presents a neater appearance.

Matrimony Vine. If there is a bare, rocky or weedcovered bank around your home or in your community that is more or less of an eye-sore, by all means transform it into a background of beauty by planting the Matrimony Vine along it. It is made for such places, and with its purple flowers and later its crimson berries is one of the most artistic vines of them all. A very rapid grower, extremely hardy, in addition to having good foliage.

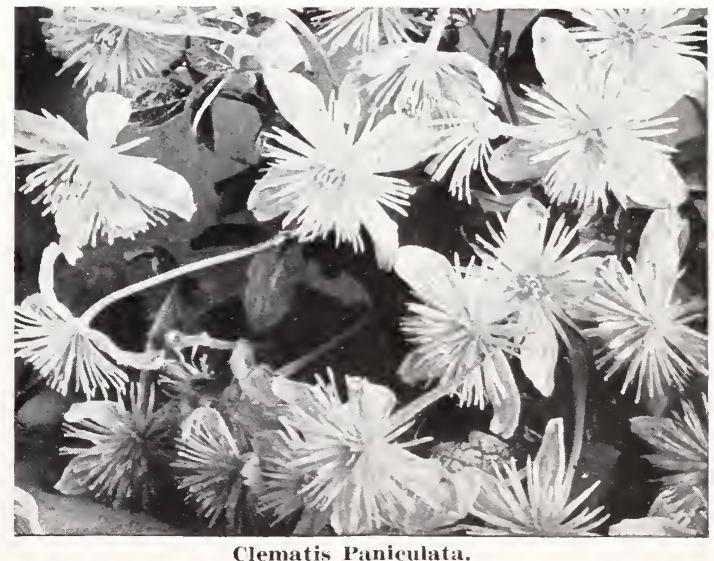




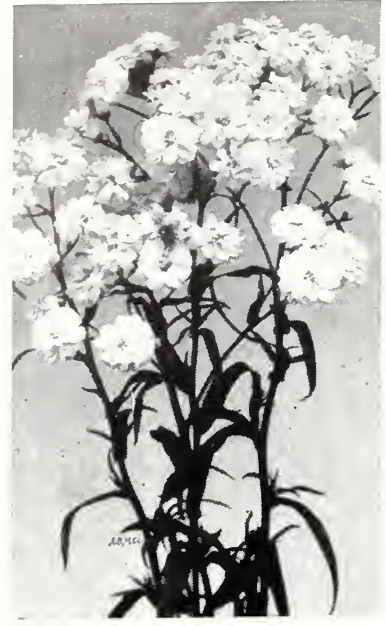

Achillea-The Pearl.



Dicentra-Bleeding Heart.

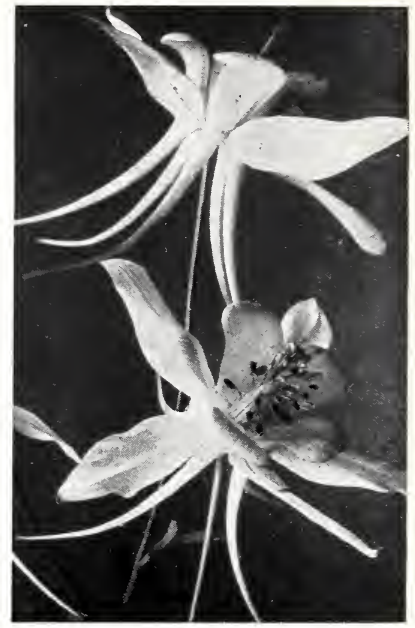

Aquilegia-Columbine.

\section{Hardy Perennial Plants}

Of all the plants that are cultivated for purely ornamental purposes there are none which have made such rapid strides in public favor as the OLD-FASHIONED HARDY GARDEN FLOWERS, the inhabitants of the perennial garden. Their popularity is not at all surprising when we consider the many varied and pleasing changes which take place throughout the entire growing season in a well arranged hardy border. Every week-yes, every day-brings forth something fresh and new to interest and delight even the most critical. Beginning in April the early tulips open their flowers often before the snow has entirely disappeared. These are soon followed by the Early Siberian Iris. Early June brings a wealth of the most magnificent bloom in all colors from the much improved varieties of Peonies. Throughout the Summer in constant succession come a wealth of flowers furnished by the Larkspur, Late Iris, Late Peonies, Sweet William, Achillea, the Pearl, Achillea roseum, and in the late Summer, Dahlias, Golden Glow, Gladioli, and Phlox. When the Summer flowers are gone the growing season is greatly lengthened by the late Fall blooms of such as the Shasta and Giant Daisies, Gaillardia and the early frosts do not touch the heavy bloom of the choice varieties of Phlox. While there are many more perennials, we list here only those that have proved entirely satisfactory in our section.

Plant in Borders. A most satisfactory arrangement is to plant perennials in a border which can follow a wall, fence, hedge or trellis. Plants should be placed in small groups, three or more of each variety together, and so positioned as to give pleasing combinations of bloom. In such a border the taller growing sorts could be used as a background. Next, place the medium heights and then the lower varieties at the edge. Desirable locations are also found in the foreground of shrubbery groups or borders. Here their Summer bloom will add color to the foliage of the shrubs which in turn furnishes a needed background for the perennial flowers.

\section{Achillea, the Pearl}

A handsome plant attaining a height of two feet, producing pure white flowers in the greatest profusion the entire Summer. One of the best varieties for cut flowers.

\section{Aquilegia - Columbine}

The Columbines are justly called one of the most graceful and hardy plants. They produce their graceful spurred flowers on stems rising two feet or more above the beautiful divided foliage. The colors are of the most delicate hues. They are not at all particular about soil or drainage, but seem to thrive in any garden soil. Flowers are in bloom from May to July. We offer the following forms and colors:

Caerulea. Blue shades.

Chrysantha. Yellow.
Long Spurred Hybrids. Mixed. This mixture is one of the most desirable and satisfactory, the blooms exhibiting a wide range of colors.

\section{Boltonia}

Very desirable for hardy borders. Flowers vary from white and pink to lavender and blue. From 2 to $4 \mathrm{ft}$. September to November.

\section{Campanula - Canterbury Bells}

A striking biennial flower and a favorite everywhere. Plants are generously covered with large, bell-shaped flowers, pink, white, and blue in color, and make a splendid showing in either the border or shrubbery groups. Will do well in sun or partial shade, and like any good growing soil.

\section{Clematis}

Recta. Grows from 2 to $3 \mathrm{ft}$. high. Produces fragrant pure white flowers in very large choice clusters during June and July. 


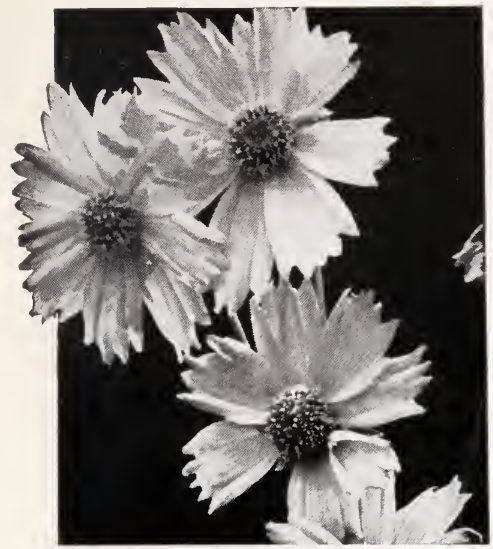

Coreopsis.

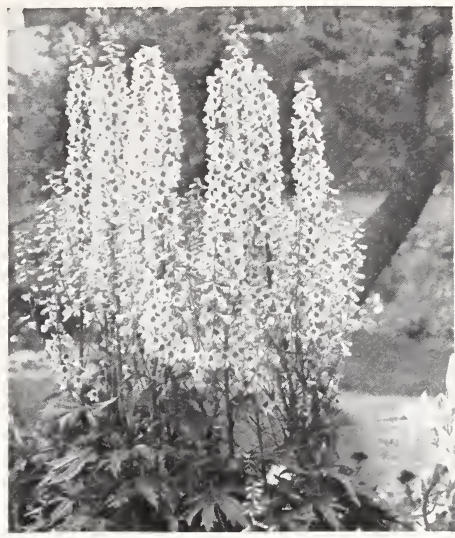

Delphinium-Larkspur

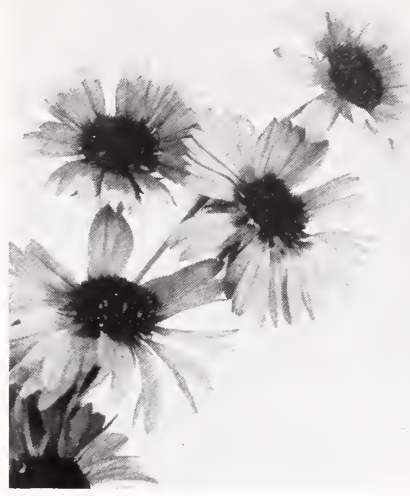

Gaillardia-Blanket Flower.

\section{Coreopsis}

This is one of the most satisfactory hardy plants for steady bloom in great profusion. The flowers are of a rich golden yellow, of good size, and the main crop comes in June. If cut every day they will continue to bloom the entire Summer in a very satisfactory manner. It is a strong grower, the clumps increasing in size each season.

\section{Daisies}

Shasta. Handsome plant with glistening foliage, dwarf type with large glistening white blossoms in June and July.

\section{Day Lily - Hemerocallis}

Here is another old-fashioned favorite that is still to be found around every old home that dates back into the last century. These hardy lilies are still favorites everywhere. They thrive in any location in good soil and are especially well adapted to moist, shady situations.

\section{Delphinium - Larkspur}

The tall English Larkspur are among the most beautiful hardy plants in cultivation. They come in several shades, and increase in size and beauty each succeeding year. The spikes are immense in size and of the most delicate shades of blue. They begin to bloom in June, and if the flowers are cut off near the ground as soon as they have faded, a second and third crop will be produced before the end of the season. It is a good plan to stake the stalks when they attain a height of three feet, as a heavy wind will frequently mutilate them.

Gold Medal Hybrids. A choice strain containing many forms and many shades.

Belladonna. Light sky-blue. Splendid cut flower variety. Used extensively by florists everywhere.

Bellamosa. A dark blue of the type of Belladonna.

\section{Dianthus}

(Also known as Pinks or Sweet William)

One of the best and most satisfactory old-fashioned plants producing in early Summer a splendid effect of rich and varied colors. We furnish them in assorted colors. Suitable for rockeries and dry sunny locations.

\section{Dicentra - Bleeding Heart}

Everyone loved the old-fashioned Bleeding Heart that our grandmother always grew in her hardy garden. For many years they were imported from Holland, but when the Government stopped the shipments by embargo, they became very scarce. They are now becoming more common and we expect to have our usual supply each year. The long racemes of heart-shaped, pink flowers are always attractivce. Comes up early in the Spring and flowers immediately.

\section{Digitalis - Foxglove}

The old-fashioned Foxglove that was always found in grandmother's hardy garden is just as popular as it was a hundred years ago. The strong stalks attain a height of 3 to 4 feet, rising from rich masses of leaves, always giving an appearance of strength to the border, and, during their period of flowering, frequently dominate the whole garden. The leading shades are white, rose and purple. We handle them in mixed shades only.

\section{Gaillardia - Blanket Flower}

One of the showiest of hardy plants, attaining a height of two feet and suceceding in any soil in a sunny position. It begins to flower in June and continues the entire season. Will do best if cut frequently. The flowers are of gorgeous coloring, the center dark red brown, while the petals are marked with rings of brilliant crimson, orange and vermilion, and often a combination of all in one flower. Should be planted in lots of six to twelve to get a good variety of shades of coloring.

\section{Gypsophila - Babysbreath}

Did you ever notice the large displays of bloom of this hardy plant in the florists' windows in late Fall? They use it extensively for ornamentation, as the flowers are minute and attractive when dry, and are borne in such great profusion. The Gypsophila will thrive in any soil, and has a large, massive root which causes the plant in Summer to throw out hundreds of branches with very scant foliage, which in the Summer and Fall is covered with the most delicate, minute white flowers, having the appearance of a misty bloom. There is really no other plant to take its place as it stands in a class by itself, and at least one plant should be in every garden. 


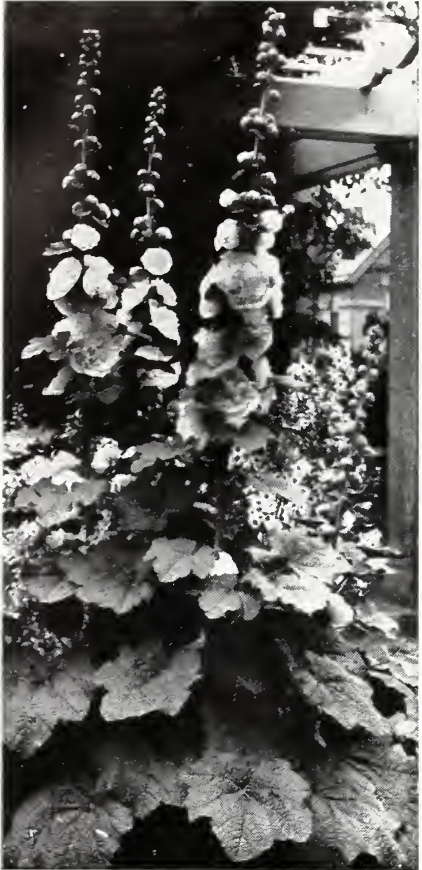

Hollyhocks.

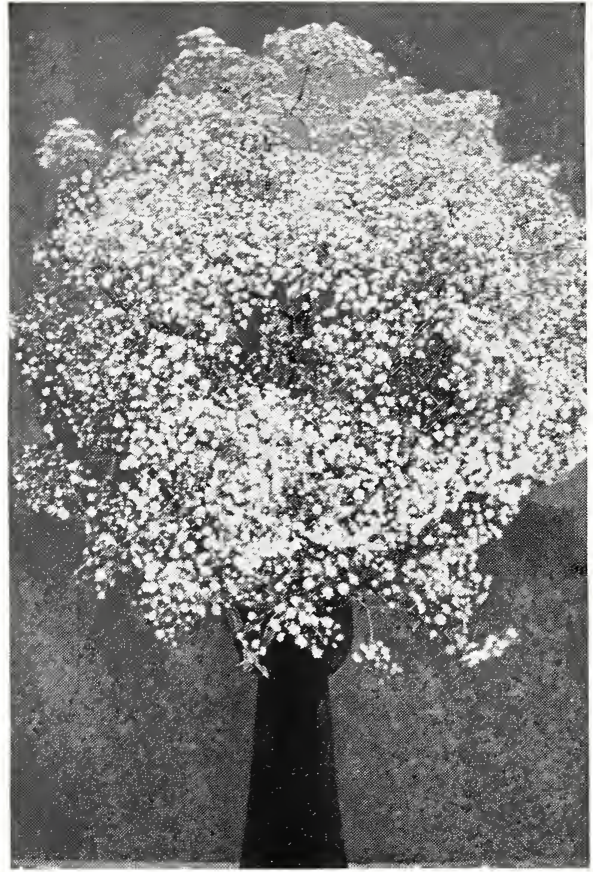

Gypsophila-Well Named Baby'sbreath.

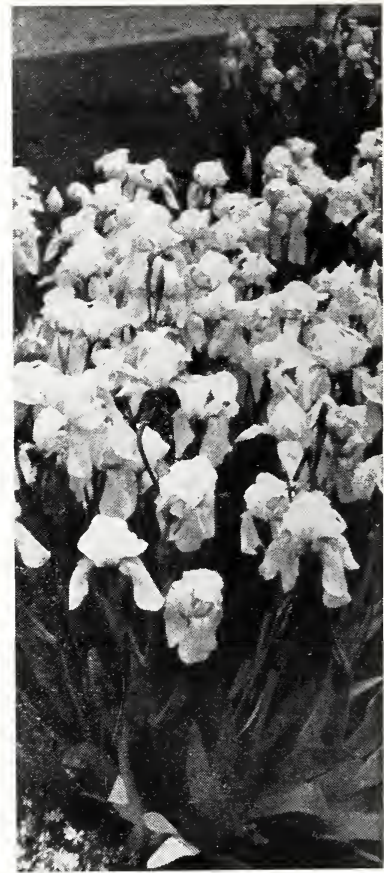

German Iris.

\section{Hollyhocks}

These stately, majestic plants are as old as the country, but the choice double varieties are not so well known. They grow 6 to 8 feet high and are a necessary part to every old-fashioned garden. They are much used in shrubbery beds, where they come up every year and add to the beauty of the surroundings. There is no other plant that takes the place of the Hollyhocks. The flowers begin to open from the bottom of the stalk and are in bloom for several weeks.

\section{Iris, German}

Has been cultivated and improved to such an extent that from the old "Blue Flag" has been evolved a most bewildering assortment of shapes and colors that it is no wonder it has been called the Rainbow Flower. In its different classes and varieties the Iris has become one of the most popular of all perennial plants and is one of the standard kinds needed to complete the hardy flower garden. Iris are also invaluable as cut flowers. If they are picked as the buds are about to open, and allowed to expand indoors, the colors will be much richer and they will last a long time, for, as fast as one flower fades the next will take its place until all have opened. Iris can be grown in any kind of soil.

I. Gajus. Maroon red effect. Very attractive.

I. Juniata. Clear blue-violet. Large flowers and sweet scented.

I. Perfection. Lavender-violet, shaded deeper violet.

I. Pumila. Dwarf; very deep blue. Very early.

I. Quaker Lady. A very attractive "sinoky blend" of lavender, yellow, blue and olive-buff.

I. Shrewsbury. Lilac and purple.

\section{Lantern Plant - Physalis}

A perennial with something of the habits of the Lily-of-the-Valley, in that it spreads from pips in the roots, and will in time fill up a small corner of the yard. The flowers are not conspicuous but the "red lanterns" which come in the Fall are very attractive. The plants can be cut near the ground in the Fall and the lanterns will dry in their natural shape and stay on for an indefinite period.

\section{Lily-of-the-Valley}

After the long, cold Winter of the North it is pleasant to see the Lily shoots coming through the ground, one of the earliest signs of Spring. The leaves quickly appear and before we hardly realize that Summer is here, the little racemes of bell-shaped flowers, which are so intensely fragrant can be gathered in quantity. A small cluster in the library will perfume the entire home with a fragrance that is both rare and elegant in nature.

\section{Lychnis - Campion}

Dense heads of brilliant orange-scarlet flowers throughout the Summer. One of the best known and loved of the old-fashioned flowers. They are of the easiest culture and most pleasing habit. The name lychnis signifies a lamp, in allusion to the cottony leaves of some of the species, which were used by the ancients as wicks for lamps.

\section{Platycodon - Balloon Flower}

These plants are closely allied to the Campanulas and form neat-branched bushes of upright habit. They grow two feet high, producing their blue or white flowers from July to October. 


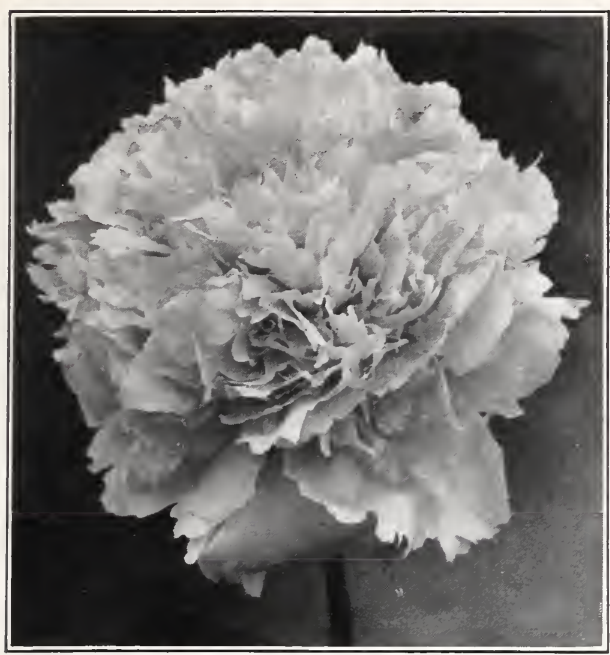

Karl Rosefield.

\section{Peonies}

Without doubt, Peonies are at the present time the most popular of all hardy plants, and justly so, for probably there is no other class of plants that combines so many desirable qualities with so few objectionable ones. They are easy to grow, hardy everywhere without protection, and free from diseases and insect pests. Once established they are permanent, large clumps being frequently seen in old, neglected gardens that have flourished and bloomed for a score of years with no attention whatever. Many new Peonies have been developed within the past few years which far surpass the older kinds in size and beauty. From the many hundreds of varieties we have selected the following as among the best.

Edulis Superba. Very large bloom of perfect shape, fine brilliant pink, shaded violet. Silvery reflex. One of the best.

Felix Crousse. Large ball shaped bloom. Brilliant red, ruby flame-colored center. An exceedingly choice peony.

Festiva Maxima. Large, very double, pure white; center petals fringed with red; long stems.

Karl Rosefield. Dark crimson, very strong, tall, compact grower and Fall bloomer, midseason. A very brilliant and striking variety.

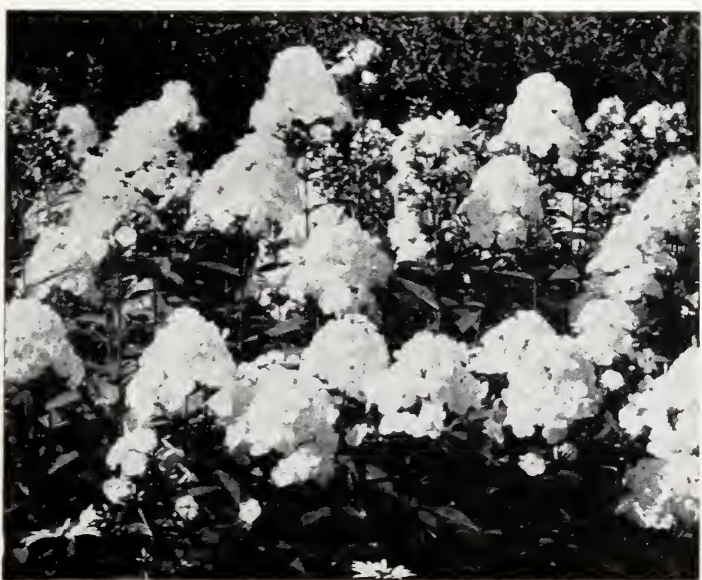

Hardy Phlox.

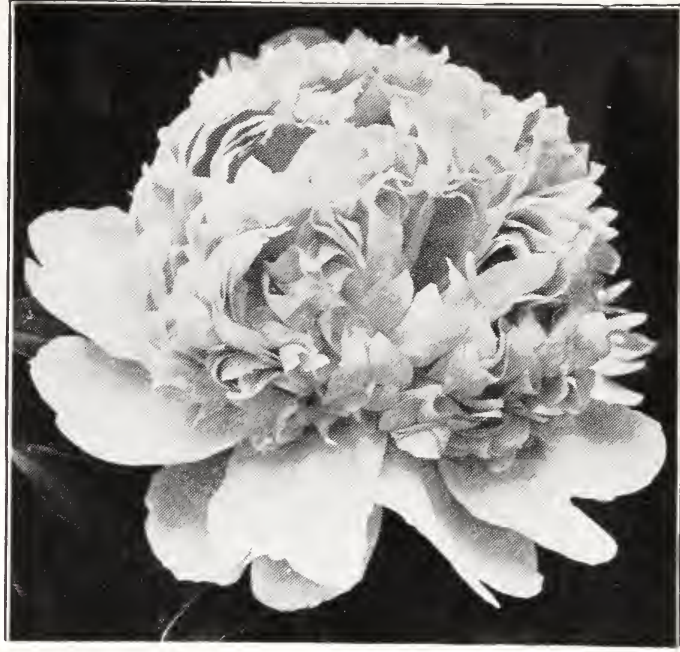

Mons. Jules Elie.

Marechal Vaillant. One of the largest red varieties. Late bloomer.

Modeste (American Beauty). Large bomb type with blooms of light red shading to pink.

Mons. Jules Elie. Very large and full flower, fairly glossy flesh-pink. Vigorous grower and free bloomer. One of the very finest peonies.

Rubra Officinalis. Brilliant red. Valuable as the earliest to bloom.

\section{Phlox}

This delightful flower gives us striking, brilliant color effects in July and August. The Phloxes may be had in crimson, white, pink and combinations of colors. They fill in that period between the early Summer flowers and the Fall blooming sorts, hence are rather necessary to furnish continuous color to the perennial landscape border. They show up very effectively when several plants of one variety are massed to give a single color in one group, or they may be used as single plants. Phloxes have been wonderfully improved during recent years; the flowers are larger and colors more beautiful. This new Phlox will surely please you. We recommend the following as being the best:

Champs Elysees. Brilliant, rich and highly pleasing to the eye. French purple, Amaranth red or wine color. Very striking and popular.

Hindenburg. Recent importation, exceptionally choice. Flaming bright red, large trusses.

Independence. Pure white, very prolific, sturdy and dependable.

Pantheon. Rose-pink shading to scarlet eye.

Richard Wallace. White changing to crimson eye. Large trusses which flower freely. Coloring beautiful shade of deep salmon-pink overlaid with scarlet, small analine-red eye. Strong, vigorous grower gaining in popularity. One of the best.

Thor. A most beautiful and lively shade of deep salmon-pink suffused and overlaid with a scarlet glow. A light, almost white halo surrounds the analine red eye. A very effective color and becoming more popular each season.

\section{Rudbeckia - Golden Glow}

One of the most popular hardy plants, a strong grower, attaining 5 to 6 feet and produces in August masses of golden yellow flowers, in form like a cactus dahlia. 


\section{Bulbs for Fall Planting}

(Cannot be Supplied for Spring)

When the snow has gone and the eye hungers for the first sign of Spring, nothing supplies so much satisfaction as a bed of bright colored, earlyflowering Tulips. Tulips are easy to grow. The important thing is to cover with five inches of earth, and to provide good soil below in which the roots may develop. Varieties and prices differ greatly. We have selected a list of choice varieties which we offer below to our customers. We supply only the strong, No. 1 bulbs.

\section{Early Cottage Tulips}

\section{(May-Flowering)}

Prince of Austria. Orange-scarlet; very fragrant; early.

Cottage Maid. Delicate rose, center of petals feathered white.

Inglescombe Yellow. Pure canary-yellow, the very best.

Keizerskroon. Red and Gold, suggesting red cap and gold crown. One of the showiest varieties.

\section{Darwin Tulips}

Baron de la Tonnaye. Bright rose; very tall and stately; excellent.

Bartigon. Carmine-red.

Centenaire. Violet-rose.

Clara Butt. Salmon-pink.

Farncombe Sanders. Rose-scarlet.

King Harold. Deep purple-red.

Margaret. Soft pink.

Nauticus. Cherry-pink.

Pride of Haarlem. Rose-carmine.

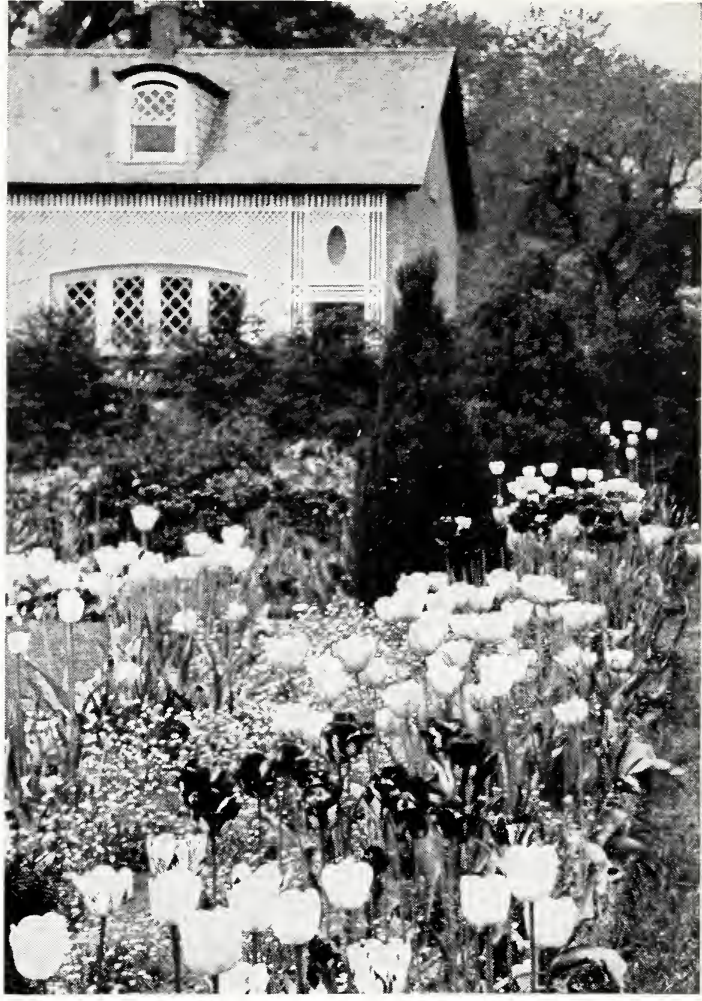

Tulips and Lily-of-the-Valley in Border.

Rev. Ewbank. Lavender-violet.

Sultan. Maroon-black.

\section{Bulbs for Spring Planting Only_Dahlias}

The wonderful improvement in the Dahlia of late years has brought it to greater prominence than it enjoyed even in our grandmothers' days. The new types are all distinct, each having a beauty peculiarly its own. They are particularly desirable for planting against fences and buildings; they do not require a great deal of care, and both flowers and plants make an exceedingly handsome display. No flowers are so easily grown. Good soil, water and sun is all they require. Plant early in May; cover the tubers about three inches deep. The following high-priced choice varieties are offered to our customers at popular prices, to assist them in showing at flower shows.

Bonnie Brae (Cactus). Peach-pink to lavender. Countess of Lonsdale (Cactus). Salmon-pink. Darleen (Decorative). Deep pink. Gay Paree (Cactus). Autumn colors. Golden Queen (Decorative). Yellow. Helen Hollis (Show). Deep scarlet.
Pride of California. Large; deep red.

Helen Keller (Peony). Rose-pink.

King of Commerce (Peony). Burnt orange.

Latonia (Peony). Buff yellow.

Maude Adams (Show). Lavender, pink and white. Novelty. Silvery rose.

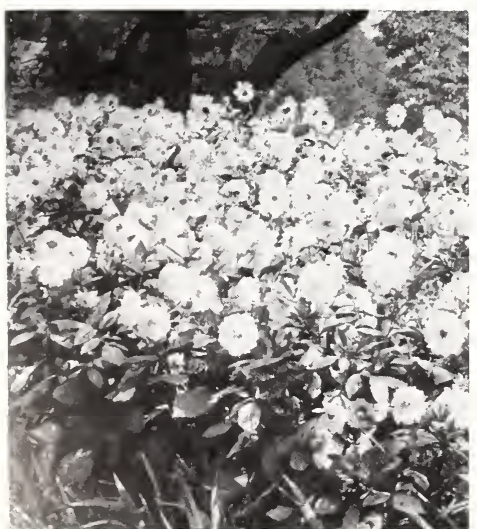

Decorative Dahlias.

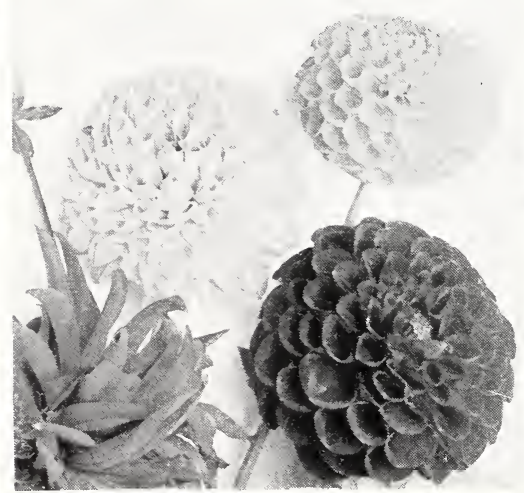

Pompon Dahlias.

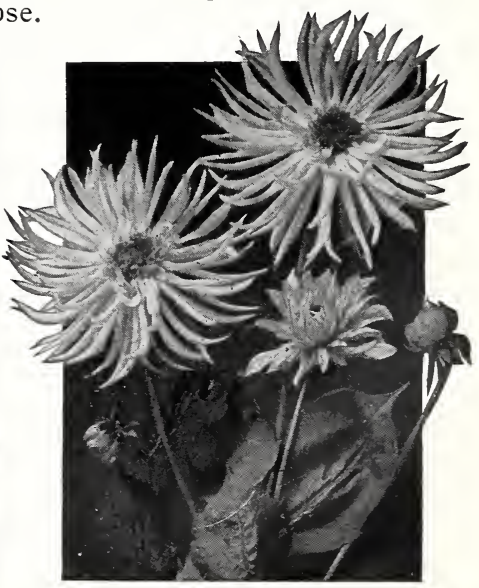

Cactus Dahlias. 


\section{Gladioli}

The interest in Gladioli throughout the country is almost equal to that taken in the Peonies. They are easy to grow, like an onion, which the bulb somewhat resembles, and are prompt to send up the most gorgeous flower stalks. There is money in growing Gladioli as well as Dahlias for the flowers, and many small home owners put in a few hundred bulbs and sell many times their cost in flowers the first season, whereas they have had the pleasure of growing and admiring them during the Summer.

The following choice list is offered our customers at low prices. The list contains many prize winners from the best shows.

Anna Eberius. Rhodamine purple, with deep blotch. Crimson Glow. Deep scarlet-crimson.

Lily White. White.

Marechal Foch. Pink throat, crimson striped.

Mrs. Dr. Norton. Finest clear pink.

Panama. White splashed shell-pink.

Peace. White with lilac markings.

Prince of Wales. Salmon-pink, with pale pink throat. Schwaben. Soft pure yellow, with purple blotch. Virginia. Intense scarlet, slightly deeper in throat. Wilbrinck. Pale pink, with yellowish markings. Willie Wigman. Rose, with crimson blotch.

\section{The Amateurs Guide to Land. scape Gardening}

This little book is designed to assist the home owner to understand the first principles of landscape gardening. It is easy to read and beautifully illustrated. This book will be furnished to our customers free upon request. Ask for it.
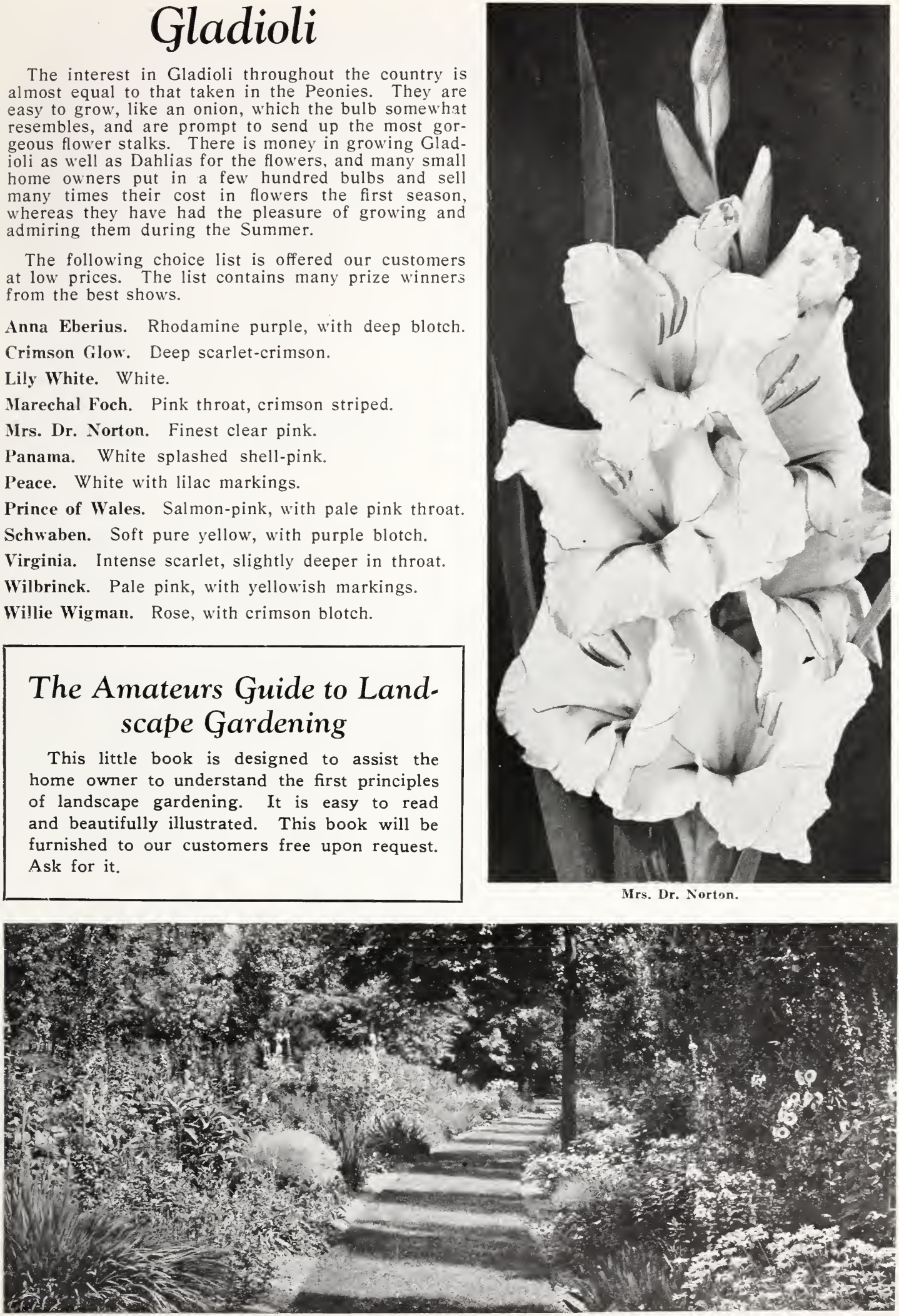


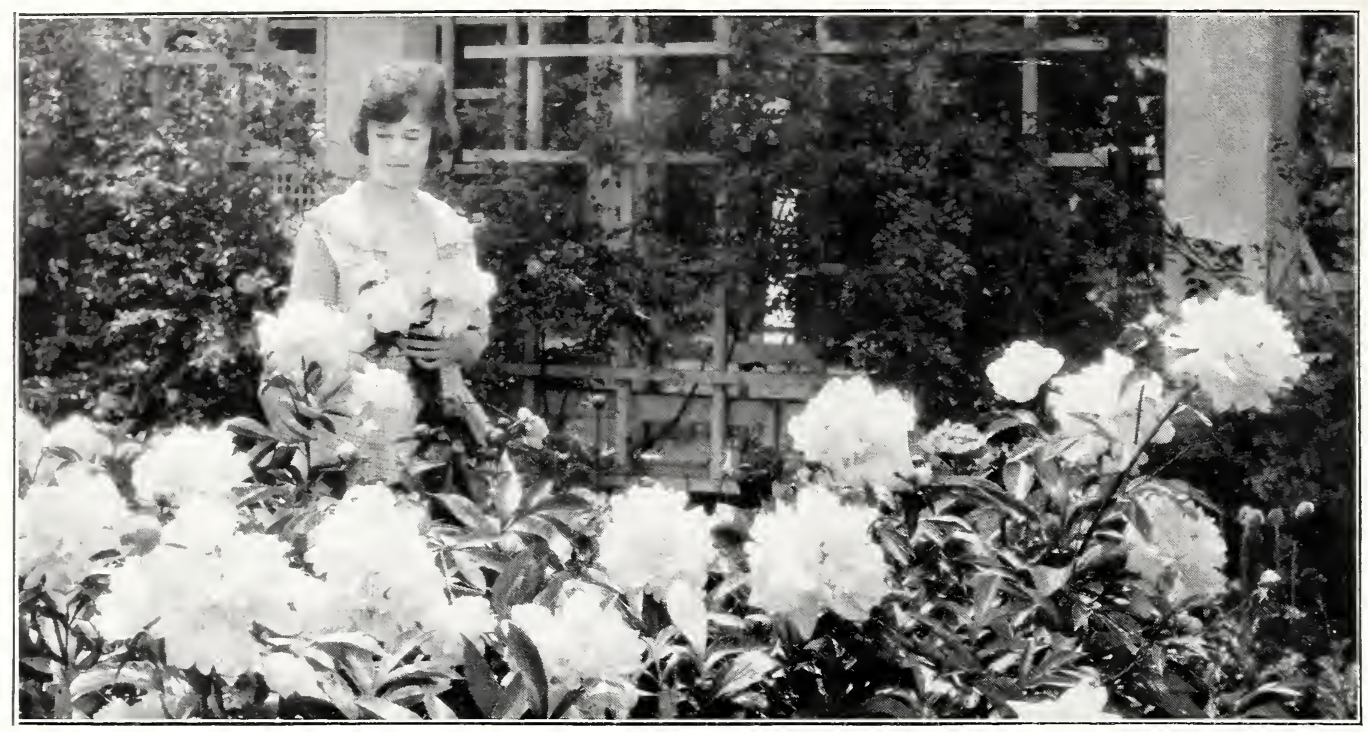

Festiva Maxima Peonies.

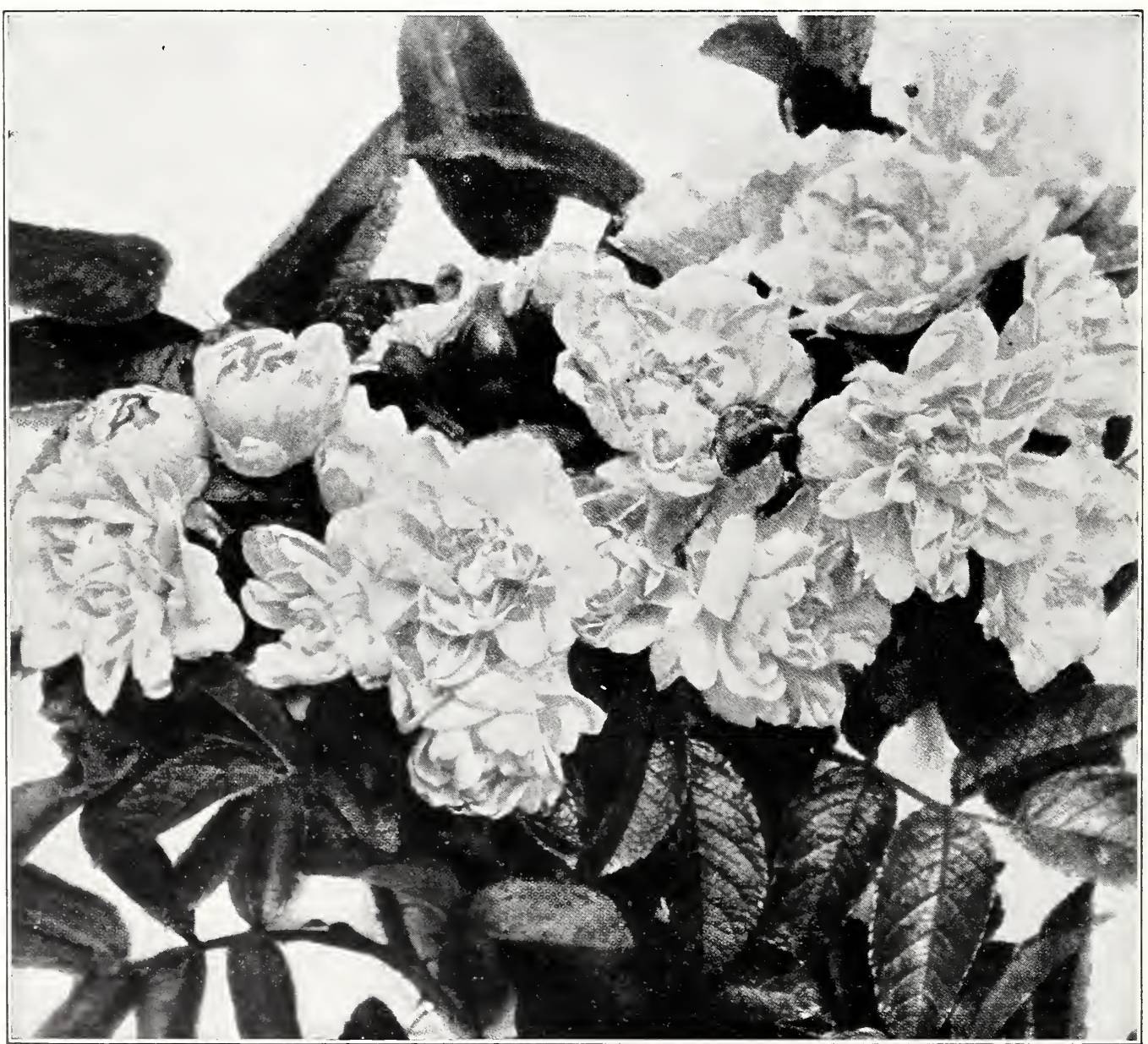

